\title{
Researching on the Countermeasures of College Students in Subjectivity Ideological and Political Education Model
}

\author{
Yan-qiang Lou \\ Graduate Department \\ Hebei Finance University \\ Baoding, China
}

\author{
Ji-na Li \\ International Education College \\ Hebei Finance University \\ Baoding, China
}

\begin{abstract}
In the ideological and political education at colleges and universities, the subjectivity model focuses on the overall, harmonious and sustainable development of both the educator and the educated and embodies the goal of value that the college and university education point at. Therefore, we must perform the goal system of the ideological and political education, establish the studentcentered core idea, and consolidate the self-education function so as to realize the life-based ideological and political education. This paper discusses the necessity of subjectivity ideological and political education model at colleges and universities. It proposes several effective ways to improve ideological and political education, including changing idea, highlighting student leading position, actively guiding students to participate in social practice and focusing on the development of their ability of technology and so on. This paper can provide some reference for students in improving the ideological and political education and improve the effectiveness of ideological and political education at colleges and universities.
\end{abstract}

Keywords: colleges and universities; ideological and political education; subjectivity education model

\section{INTRODUCTION}

Subjectivity, as an essential attribute of human, is displayed in the process of its interaction with objects. In the daily ideological and political education for college students, education model between subjects, advocates a model of two-way interaction and mutual respect between subjects, which is mainly demonstrated in achieving mutually complementary advantages of both the education and the courses of ideology and politics, widespread, temporary and special ideological and political education by constructing an E-platform, cultivating the students' subjective personality by innovating the social practice model, and also in developing students' subjective awareness by improving psychological guidance. The essence of overall human development is quality improvement and the essential feature is overall development of subjectivity. Subjectivity ideological and political education concerns people's subjectivity as well as the educational view and methodology of developing ideological quality. It has internal and essential links with overall human development theory of human beings.

When carrying out ideological and political education, many colleges and universities neglect the main body of the students, which hinders the development of students' initiative and creativity to some extent. Therefore, When carrying out ideological and political education under the circumstances of subjectivity ideological and political education model, colleges and universities should adhere to the people-oriented concept, highlight student status and promote the students' comprehensive development. Therefore, colleges and universities should change idea, highlight student leading position, actively guide students to participate in social practice, pay attention to the guidance of students' scientific and technological innovation and promote the students' comprehensive development.

\section{The necessity of subjectivity ideological and political education model}

From the perspective of subjectivity ideological and political education at colleges and universities, educators and educators are mutual relationship between subject and object. From the educator level, teachers are the subject of ideological and political education and students are the object of ideological and political education. From the level of education, students are the subject and teachers are the object. At present, the environment, contents and forms of Ideological and political education have changed profoundly. The traditional ideological and political education idea has lagged behind. It is difficult to effectively improve its effectiveness. When carrying out ideological and political education, colleges and universities use subjectivity education model can change idea, highlight student leading position, actively guide students to participate in social practice.

\subsection{It is the essence of the development of the scientific concept}

The essence and ultimate goal of Marx s theory are achieving the full and free development of human. Its related theory provides a solid philosophical basis for subjectivity ideological and political education at colleges and universities. In recent years, with the deepening of 
reform and opening up, our country is increasingly close to the world. That ideas and culture continue to shock the minds of students has formed a severe challenge for ideological and political education. In this regard, in order to make students adapt to the development and needs of the society, colleges and universities should guide the students correctly, improve and innovate the way and content of ideological and political education and cultivate the students' ability of self judgment. Establishing the subjectivity status of human, understanding value of the people and promoting the students' comprehensive development are the main goals of subjectivity ideological and political education at colleges and universities.

\subsection{It is the inherent requirement of changing the traditional education model}

Traditional ideological and political education model takes the teacher as the main body, student as object. It easily leads to the object away from the subject, theory divorced from reality. However, subjectivity ideological and political education model takes the student as the main body. It emphasizes the people-oriented concept, contradictory view of the relationship between subject and object. While playing the main educational advantages, it can effectively learn from the essence of traditional education to improve the effectiveness of ideological and political education. It should combine with moral character to form regular pattern, formulate scientific moral education target from the perspective of reality and the ideal and improve the efficiency of ideological and political education.

\subsection{It can improve the effectiveness of the ideological and political education}

The ideological and political education at colleges and universities should have scientific and reasonable target. It needs taking the relevant measures to ensure the organic combination of ideological and political education theory and practice to improve the effectiveness. It not only needs the scientific theory basis, but also needs the joint efforts of teachers and students. In subjectivity ideological and political education model, teachers and students are mutual the main body and enhance the effectiveness of the subjectivity education under the mutual respect and encouragement.

\subsection{It is effective practice of the value of ideological and political education at colleges and universities}

Traditional ideological and political education model focuses on social value of ideological and political and ignores the value of the individual to a certain extent. It is difficult to improve the effectiveness of ideological and political education. Subjectivity ideological and political education model emphasizes the subject existence of human beings. It focuses on promoting the full development of human, promoting the students' main spirit and respecting the development of students' personality and personality.

\section{The effective ways of improving the ideological and political education under the circumstances of subjectivity ideological and political education model}

This paper proposes several effective ways to improve ideological and political education, including changing idea, highlighting student leading position, actively guiding students to participate in social practice and focusing on the development of their ability of technology and so on.

\subsection{Changing ideological and political education ideas}

Influenced by traditional education idea, many colleges and universities take the teacher as the main body and neglect the students' subjectivity. Under these circumstances, students can only passively accept the knowledge and could not meet the needs of the rapid development of society. Therefore, students should be the subject and the initiative and independent individuals. Through the inspiration and guidance of the inner ideological and political needs, it can cultivate the consciousness of the subject and the creation ability and promote students' free and comprehensive development. in order to improve the efficiency of ideological and political education, colleges and villages should pay attention to listen to the views and suggestions of the students and carry out ideological and political education.

\subsection{Highlight students' leading position}

Students are the subject of ideological and political education, not only the participants of the ideological and political education. Therefore, it Should highlight the dominant position of students, respect the students' independent personality, develop students' role in the ideological and political education. At the same time, colleges and universities should also create the conditions for the students to develop their potential, cultivate students' creative consciousness and exercise innovative thinking and practical ability. In addition, colleges and universities should combine the main development needs and real needs of students, use persuade education, demonstration and guidance and other ways, build democratic and equal exchange environment and stimulate students' potential, cultivate the consciousness of selfeducation, self-management and highly responsible for themselves and society.

\subsection{Actively guiding students to participate in social practice}

To correctly understand the society and cultivate independent living skills, colleges and universities should actively guide students to participate in social practice. Colleges and universities should establish a sound mechanism and improve the integration of social resources to Create opportunities of social practice for students. Colleges and universities should actively organize and conduct social surveys and social services and other related educational activities to let the students understand the 
society and service society, and cultivate the students' subjectivity.

\subsection{Pay attention to the students' scientific and technological talents}

Colleges and universities should pay attention to the cultivation of students' science and technology ability to enhance their innovative awareness. Colleges and universities should establish the perfect innovation incentive system and the guarantee system to provide institutional guarantee for student innovation. Teachers should pay attention to the guidance of students' scientific and technological innovation, mobilize their enthusiasm, let the students take the initiative to participate in various scientific and technological activities, cultivate their ability to use the knowledge to solve practical problems, so as to enhance the self-learning ability and psychological endurance ability and personal political consciousness.

\section{Conclusion}

In today's era of rapid economic development, Education is also on the development of the date of the new moon. Subjectivity ideological and political education of students at colleges and universities should also keep pace with the times. Traditional education theory and the education pattern have already did not suit the time development need, establishing subjectivity ideological and political education model is necessary. The very core of education is the human being. How to recognize and embody the importance and role of the human being in education is concerned with the ideological and political education nowadays. It is of great theoretical and practical significance to study the subjectivity of the young university men in order to meet the serious challenge confronted with the ideological and political education of colleges and universities, improve the idea of the ideological and political education, strengthen the pertinence and effectiveness of the ideological and political education and facilitate the growth and success of the university men. Colleges and universities adopt subjectivity ideological and political education model can effectively improve the effectiveness of ideological and political education. Therefore, colleges and universities should change idea, highlight student leading position, actively guide students to participate in social practice, pay attention to the guidance of students' scientific and technological innovation and promote the students' comprehensive development. This paper discusses the necessity of subjectivity ideological and political education model at colleges and universities. This paper can provide some reference for students in improving the ideological and political education and improve the effectiveness of ideological and political education at colleges and universities.

\section{References}

[1] Yan Yin, "A reflection on the construction of the ideological and political education subjectivity model at colleges and universities," Journal of Mianyang Normal University, pp. 116-120, 2011.

[2] Yansong Chu ,"The construction of college students' subjective ideological and political education model," Education and Occupation, pp. 44-45,2013.

[3] Xianjin Zhou ,"The ideological and political education of the main body is inevitable," Forward position,pp.915,2010 .

[4] Zhangwei Cheng, "Researching on the subjectivity ideological and political education model in colleges," Journal of Kaifeng Institute of Education,pp.204205,2013.

[5] Xiaohong Li, "The application of education model between subjects in the daily ideological and political education for college students," Social Sciences Journal of Universities in Shanxi,pp.71-74,2013.

[6] Runguang Qian, "Suggestions of forming a Pattern of Political and Ideological education," Journal of Qujing Teachers College,pp.5-8,2004.

[7] Jinping Wang, "The discussion of subjective ideological and political education," Forward Position,pp.84-87,2014.

[8] Lianru Hao, "The status and prospect of the research on subjectivity ideological and political education,"

Journal of Changchun University of Technology(Higher Education Study Edition),pp.118$120,2015$.

[9] Changwei Guo, "Subjectivity-oriented ideological and political education: the essential requirement of overall human development," Journal of Guangxi Youth Leaders College,pp.39-41,2014. 